\title{
REPRESENTATIONS OF IDEOLOGICAL AND CULTURAL VALUES IN MODERN RUSSIAN POLITICAL DISCOURSE
}

\author{
Tatiana Dubrovskaya \& Tatiana Kharlamova \\ Penza University of Ecology and Political Sciences \& \\ Saratov State University, Russia
}

\begin{abstract}
Resumen: Este artículo ofrece una visión del discurso político ruso actual y analiza 16 discursos pronunciados por presidentes rusos a la Federal Assembly (Asamblea Federal). Se ha tratado de demostrar que existe una relación tripartita entre lenguaje, ideologías políticas y valores culturales. El análisis del discurso nos permite señalar conceptos primordiales y palabras claves que encarnan valores culturales e ideológicos, tal y como se encuentran en los textos. A través de los ejemplos tomados de los discursos se ilustran supuestos teóricos sobre las relaciones de poder y el nivel de individualismo/colectivismo en la Rusia actual.
\end{abstract}

Palabras clave: discurso político, presidente, ideologías, valores culturales.

Abstract: The present paper provides an insight into modern Russian political discourse and offers the analysis of 16 speeches delivered by Russian Presidents to the Federal Assembly. An attempt has been made to demonstrate that there exists a tripartite connection between language, political ideologies and cultural values. The analysis of the discourse allows to single out principle concepts and key words which embody cultural and ideological values, as they are embedded in the texts. Theoretical assumptions on power distance and the degree of individualism/collectivism in the modern Russia are illustrated with instances of discourse.

Keywords: political discourse, president, ideologies, cultural values.

\section{INTRODUCTION}

The present paper provides an insight into modern Russian political discourse and offers some suggestive conclusions as to how cultural and ideological values are embodied in language.

The idea that ideologies are created, practised and maintained by means of language is not novel. Modern scholars of Critical Discourse Analysis (CDA) have reached considerable results in explaining how language and ideology are interrelated. Similarly, a lot has been written about the connection between 
language and national mentality, the latter being expressed through language. In this paper, drawing on the achievements of CDA and cultural studies, we have made an attempt to step further and reconcile the critical view on discourse with the analysis of cultural values. We have tried to demonstrate that there is a tripartite connection between language, political ideologies and cultural values. While the minutiae of interaction can tell us a great deal about political behaviour, we shall concentrate on cultural and ideological values embedded in the texts.

To attain this goal of the study, we have undertaken a multi-disciplinary approach. The methodological framework of the study encompasses the theory of cultural dimensions, as developed by Hofstede (Hofstede 2001), principal developments in Russian cultural studies, and results of social research conducted by sociologists in the modern Russia. Linguistic analysis of speech data carried out in the present study is viewed as a key to understanding social processes that are under way in the country. The research is based on the content analysis (qualitative and quantitative) which leads to determining key words that embody principal ideological values of the current moment, as well as explaining the causal effects of discourse on social life.

The data of the research is comprised of 16 speeches that Russian Presidents B. Yeltsin, V. Putin and D. Medvedev delivered to the Federal Assembly of the Russian Federation in 1994-2009. Translations of the presidents' addresses have been taken from the official website of President of Russia (eng.kremlin.ru). In order to shed light on the interaction between the authorities and the public, materials of the President's blog have been explored (2009). Translation of the blog entries into English has been done by the authors of the present article.

The article consists of 5 parts. It begins with the introduction. In part 2, we discuss the concepts of ideology and cultural values and define our own approach to these concepts. In part 3, we focus attention on the cultural dimension "Power distance" and present the outlook on Russian mentality in terms of attitude to power distribution and power distance. The theoretical assumptions are followed by the practical analysis of speech data which shows how power distance is established and maintained by means of language in political discourse. In part 4, we elaborate on the dimension "Individualism versus Collectivism" and discuss the importance of the concepts in question for the Russian community. The linguistic analysis that follows is aimed at throwing light on how these concepts are presented in political discourse. In part 5, the main results of the study are summarised and concluding remarks are made.

\section{THE CONCEPTS OF IDEOLOGY AND CULTURAL VALUES}

Now that we have defined the goals and method of the present study and presented the data under analysis, it would be appropriate to focus on the concepts of ideology and cultural values as these are key terms in the article. We 
shall demonstrate that ideology and cultural values are inextricably intertwined and, therefore, should be viewed in a combination.

The term ideology has been exploited intensively and extensively across a number of disciplines, including history, philosophy, political economy, anthropology. Linguistics, especially the study of language as a social phenomenon, cannot be excluded from this number. However, as Scollon \& Scollon point out, "the word 'ideology' is a difficult one to use, because it has been used in so many different ways in the two hundred years or so of its existence" (Scollon, Scollon 2005: 131).

With exactly the same idea Blommaert starts his discussion of "the terminological muddle of ideologies" and notes (Blommaert 2005: 158):

Few terms are as badly served by scholarship as the term ideology, and as soon as anyone enters the field of ideology studies, he or she finds him/herself in a morass of contradictory definitions, widely varying approaches to ideology, and huge controversies over terms, phenomena, or models of analysis.

In his attempt to elaborate the term, Blommaert distinguishes two major traditions of conceptualizing ideology. The scholar connects the first tradition with Marxist theory in which ideology is interpreted as "tied to the interests of particular social groups and to processes of power and dominance" (Blommaert 2006: 510). In the second tradition of social studies, ideology is understood as collective psychology that is made up of ideational complexes which present the deeper layers of culture and society and turn groups of people into communities, societies and cultures (Blommaert 2006: 510). This understanding of ideology is neutral and characteristic of anthropological, ethnographic studies.

While Blommaert prefers to focus on the ethnographic tradition, most discourse analysts undertake the approach resting on a close connection between ideology and power. Scollon \& Scollon define ideology as "a system of thinking, social practice, and communication, which is used either to bring a particular group to social power or to legitimate their position of social power..." (Scollon, Scollon 2005: 131).

The interpretation of ideology as inextricably linked to power relations is particularly salient within the tradition of Critical Discourse Analysis. Fairclough provides the following definition of ideology: "Ideologies are representations of aspects of the world which can be shown to contribute to establishing, maintaining and changing social relations of power, domination and exploitation" (Fairclough 2004: 9). The scholar calls this view of ideology 'critical' and opposes it to 'descriptive' views that are given without reference to power and domination.

In the present paper an approach is undertaken which combines a narrower interpretation of ideology as a complex of ideas and practices aimed at maintaining a certain social order and holding power with a wider interpretation of 
ideology as a system of beliefs and moral values which is characteristic of all people in a given speech community. We contend that these common beliefs and ideas embedded in the mentality of most people in a given speech community can be denoted by the term cultural values. Ideology and cultural values are not, as we see them, isolated phenomena. On the contrary, ideology is enacted and inculcated most successfully in the society by actualizing and exploiting certain cultural values.

The idea about the interconnection between ideology and cultural values is not absolutely novel. Turning to cultural models, Gee perceptively states that cultural models are deeply implicated in 'politics'. By 'politics' the scholar means

....anything and anyplace (talk, texts, media, action, interaction, institutions) where "social goods" are at stake, things like power, status, or valued knowledge, positions, or possessions. Since cultural models embed assumptions about what is "appropriate", "typical", and/or "normal", they are political through and through (Gee 1999: 70).

Even though the term ideology is not used by Gee, it is quite clear that ideology is involved in the distribution of social goods, first and foremost, power.

Thus, on the one hand, we have deeper perceptions of the reality and a number of beliefs which are shared by most people and regulate their social behaviour. These are more or less stable entities embedded in the people's national mentality, and it takes time to introduce any dramatic changes in people's minds. On the other hand, we have ideologies that are created for political purposes, i.e. for maintaining or changing social relations of power.

Ideologies are practised, first of all, through language. As Blommaert has indicated,

...Every act of communication articulates a metapragmatics in which the linguistic-ideological features operate. This metapragmatic, indexical layer of semiotic systems such as language is not neutral; it is evaluative, relational, socially positioned, invested with interests, and subject to contestation and dominance (Blommaert 2006: 511).

Depending on a political purpose, ideologies change, and so does the language used to actualize them. Therefore, these are more flexible entities as compared to cultural values.

In the analysis that we shall undertake further, language and discursive means are viewed as expressing both cultural values and ideologies practised at a particular historical moment. As it has been pointed out, language is never neutral, it always bears a certain cultural and ideological load. Russian scholars Kitaigorodskaya and Rosanova, discussing political communication in the Russia of the 90 s, argue that ideology finds its verbal envelope in generalised formulae, 
slogans, and a broad variety of propaganda clichés (Kitaigorodskaya, Rosanova 1996). Therefore, the analysis of discursive means in presidential discourse will let us identify the ideologies practised and detect how traditional cultural values are transformed under the influence of emerging ideologies.

The study draws on Hofstede's model of culture, according to which several socio-cultural dimensions are identified: power distance, individualism, masculinity, uncertainty avoidance, long-term/short-term orientation, and indulgence versus restraint. Every culture can be characterised by a particular position on the scale of each socio-cultural dimension. We assume that it is possible to reveal this position on the basis of linguistic analysis. Hofstede's model has not been applied widely in discourse analysis, but it has proved beneficial for social research. One of such social studies was performed by Ardichvili and Kuchinke who explored cultural values among managers and subordinates in four countries of the former Soviet Union and defined leadership styles accordingly (Ardichvili, Kuchinke 2002).

\section{POWER DISTANCE: POLITICAL DISCOURSE TRANSFORMING CULTURAL VALUES?}

Hofstede distinguishes 6 dimensions of culture, but we shall expand on those 2 of them that seem most enlightening in terms of power relations.

Power distance is, no doubt, the most important dimension in view of the type of the discourse explored. Hofstede defines this dimension as follows:

Power distance is the extent to which the less powerful members of organizations and institutions (like the family) accept and expect that power is distributed unequally. This represents inequality (more versus less), but defined from below, not from above. It suggests that a society's level of inequality is endorsed by the followers as much as by the leaders (www.geerthofstede.nl).

When applied to our data, 'the powerful' stands for the President (presidential power), while 'the followers' include the country's population as a vast and unlimited category. Russian history has demonstrated immensely complicated relations between the powerful and the followers. Many scholars of Russian culture and history observe that Russian governance has always been very strong, forceful and dominating. "...Authoritarianism was the rule in Russian governance," - notices an American author Yale Richmond who wrote his book in an attempt to find a key to understanding the Russians and explain these strange folks to the rest of the world (Richmond 1992: 67). Richmond methodically went through different periods of Russian history to illustrate Russian authoritarianism: he begins with the Tsardom of Moscow of the $16^{\text {th }}$ and the $17^{\text {th }}$ century where all the classes of the nation were bound to the service of the state, and ends with the Soviet era with Moscow's heavy hand which was found in the 
economy, culture, education, the media, religion and citizens' private lives. 'Authoritarianism', 'Moscow's heavy hand', 'force to maintain... authority' are but a few descriptors that were used by Richmond to portray Russian power.

A foreign outlook may sometimes prove a bit biased. Therefore, to reach a balanced view, it may be useful to take into account insiders' viewpoints. $\mathrm{Nu}-$ merous attempts at understanding and revealing the Russians have been made by native scholars. According to Voloshin, the explanation of Russian statism lies in the history and geographical position of the country: Russian life needed strong state power which would be able to keep together vast lands and numerous peoples (Волошин 1990: 29). Sikevich distinguishes, among other ethnic features of the Russians, subordination of an individual's life to the state interest (Сикевич 1996), which definitely presupposes the strength of the state.

The other side of power relations is the attitude of the followers to the powerful, and here we are approaching the issue central to Hofstede's model. How do the less powerful members of the society treat the present distribution of power? What are their expectations? Answering these questions, we shall return to the American study referred to previously. The quotation from Kennan, provided in Richmond's book, seems to have grasped the very essence of twoway power relations: "Forms of government and the habits of governments tend over the long run to reflect the understandings and expectations of their peoples" (Richmond 1992: 68). Although we can hardly agree with Richmond's generalised characteristic of the Russian population as a submissive citizenry accustomed to directions from above and unable of making their own decisions, there is definitely a grain of truth in his statement.

In the Soviet era communication between the powerful and the followers lacked a feedback mechanism. The powerful were heard by the followers, but the followers seldom had a chance to express their points of view, including the opinion on the distribution of power. The need of the population for dialogue with the powerful was appeased by demonstrative and rather random meetings of Soviet leaders with common people, which in fact resembled stage shows and gave the illusion of a short power distance.

Nowadays, this genre of communication between the authorities and the population is gaining popularity with modern leaders. Having realised the growing need of Russian population for the dialogue with the political elite and seeking for new means of effective communication with the electorate, the powerful responded to a newly formed social situation by exploiting more dialogic genres and inventing new forms of dialogue with people. There have appeared new forms and genres of interaction between the powerful and the people, aimed at developing a closer relationship and getting feedback from the audience: Internet sites, Internet-conferences, video blogs, audio and video messages to the country, etc. This dialogic orientation is supposed to create a new portrait of the powerful: the powerful who are ready for discussion, open to criticism and, 
therefore, close to people. In other words, the powerful demonstrate that they are open to communicate with the public and underline the efficacy of democratic principles, relevant to all members of society.

Democracy presupposes a flat hierarchy, a horizontal power structure with shorter power distance as compared to a vertical hierarchy. An appeal to democratic values is an adequate litmus test to distinguish between an authoritarian and democratic state.

Russia's experience with democracy and market economy has undergone a lot of changes, highs and lows and sudden stops. The advent of M. Gorbachev to power marks the beginning of glasnost and perestroika. Since the new Russia began its reform process, there have been two important aspects of development, including building the foundations of democracy through a new polity of obtaining a civil society, and transforming the economy. B. Yeltsin ushered in the country a process of further democratization as envisioned by him. Putin as Yeltsin's successor brought solid economic growth and, as some researchers see it, a rollback of democratic rights. Nevertheless, democracy was firmly instilled in the Russian society as a guiding line for further development of the country.

According to the definition provided by the Merriam-Webster Dictionary, the concept of democracy implies:

1. a government by the people; especially: rule of the majority; b a government in which the supreme power is vested in the people and exercised by them directly or indirectly through a system of representation usually involving periodically held free elections (The Merriam-Webster Dictionary 1995).

In the book "The Irony of Democracy" by Thomas R. Dye and L. Harmon Ziegler a broad definition of democracy includes the following points:

participation by the mass of people in the decisions that shape their lives; government by majority rule, with recognition of the rights of minorities; freedom of speech, press, and assembly; freedom to form opposition political parties and to run for office; commitment to individual dignity and to equal opportunities for people to develop their full potential (Dye, Harmon 2008).

The definition given by the Dictionary of the Russian Language renders the ideas similar to the ones quoted above (Словарь русского языка 1999).

It may be inferred from the definitions that key democratic values presuppose low power distance between the powerful and the people.

Let us turn now to the texts of Presidential Address to the Federal Assembly of the Russian Federation. Analysis of these texts can give us a clue to the solution of the issue and show how often Russian leaders resort to linguistic embodiment of democratic values in their speeches, aimed at propagating a new polity and establishing a closer rapport with the audience. What a linguistic and 
analytic account can achieve is a detailed description of the interaction between the powerful and the public with the focus on cultural and ideological values. It can also show how verbal, political and cultural components are combined.

As a tentative step, we might suppose that the shift in the Russian political system from authoritarianism to democracy is reflected in the choice of lexical units expressing values of the democratic state. Let us take a closer look at the use of the words democratic/democracy, independent/independence, equal/equality, freelfreedom, responsible/responsibility, transparent/transparency, which indicate basic reference points of a democratic society. The first four words are embedded in the definition of democracy itself, while responsibility presupposes that the powerful should report to the people trying to build up a transparent society.

The quantitative analysis of the data given shows that reference to democratic values is essential for the addresses of B. Yeltsin, who widely uses the words $d e-$ mocracy/democratic, independent/independence, free/freedom, responsible/responsibility. As it is seen from the table, B. Yeltsin resorts to democratic values at the beginning and the very end of his tenure mainly focusing on democracy, freedom and responsibility.

The 90-s was the period when new ideological views were instilled into the minds of people. The verbal component is foremost in the process of changing the mindset of people. Repetition of the reference points of a democratic society shapes a new attitude towards the new polity of the country.

It is also worth mentioning that the frequency of usage of the set of these words reached its peak in 1994-1996, while a noticeable descent is observed in 1997-1998 (except for the words responsibility/responsible). During the last year of Yeltsin's reign, there is a new wave of exploiting key words of democracy. The text works by systematically repeating democracy/democratic, freelfreedom, responsible/responsibility, transparent/transparency. The Address of 1999 is a kind of a farewell message of the first President of Russia to the future generation of politicians whose aim should be to support and develop the inculcated democratic principles.

The first addresses by V. Putin shift the focus to the economic growth and social sphere, strength and unity of the country, while democratic values recede into the background:

Our strategic task over the last year was to strengthen the state in the form of its institutions and all the levels of power. It was clear that without resolving this key issue we would not achieve success either in the economy or in the social sphere. 
Table 1. Reference to democratic values by Russian leaders

\begin{tabular}{|c|c|c|c|c|c|c|}
\hline 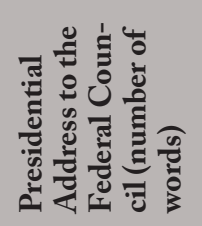 & 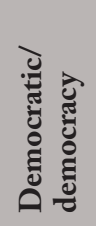 & 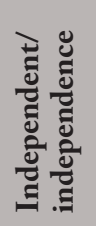 & 吾 & 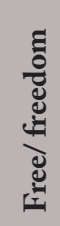 & 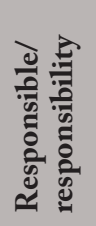 & 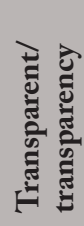 \\
\hline $\begin{array}{l}\text { Yeltsin, } 1994 \\
(15755)\end{array}$ & 42 & 14 & 1 & 38 & 20 & 7 \\
\hline $\begin{array}{l}\text { Yeltsin, } 1995 \\
(20642)\end{array}$ & 34 & 15 & 4 & 35 & 14 & 15 \\
\hline $\begin{array}{l}\text { Yeltsin, } 1996 \\
(12634)\end{array}$ & 33 & 10 & 3 & 42 & 18 & 5 \\
\hline $\begin{array}{l}\text { Yeltsin, } 1997 \\
\text { (13611) }\end{array}$ & 3 & 4 & 1 & 10 & 30 & 7 \\
\hline $\begin{array}{l}\text { Yeltsin, } 1998 \\
(14799)\end{array}$ & 6 & 8 & 5 & 10 & 25 & 9 \\
\hline $\begin{array}{l}\text { Yeltsin, } 1999 \\
(20920)\end{array}$ & 20 & 7 & 5 & 29 & 37 & 12 \\
\hline $\begin{array}{l}\text { Putin, } 2000 \\
\text { (3876) }\end{array}$ & 9 & 2 & 3 & 7 & 10 & 2 \\
\hline $\begin{array}{l}\text { Putin, } 2001 \\
\text { (5921) }\end{array}$ & 1 & 1 & 1 & 6 & 4 & 5 \\
\hline $\begin{array}{l}\text { Putin, } 2002 \\
(5686)\end{array}$ & 1 & 2 & - & 5 & 4 & 2 \\
\hline $\begin{array}{l}\text { Putin, } 2003 \\
\text { (6058) }\end{array}$ & 4 & 1 & 2 & 7 & 6 & 5 \\
\hline $\begin{array}{l}\text { Putin, } 2004 \\
(5208)\end{array}$ & 8 & 2 & 2 & 9 & 5 & 4 \\
\hline $\begin{array}{l}\text { Putin, } 2005 \\
\text { (5212) }\end{array}$ & 23 & 6 & 4 & 12 & 4 & 4 \\
\hline $\begin{array}{l}\text { Putin, } 2006 \\
\text { (6533) }\end{array}$ & 2 & 1 & 1 & 2 & 5 & 2 \\
\hline $\begin{array}{l}\text { Putin, } 2007 \\
\text { (8036) }\end{array}$ & 8 & - & 1 & 3 & 8 & 4 \\
\hline $\begin{array}{l}\text { Medvedev, } \\
2008 \text { (8492) }\end{array}$ & 26 & 5 & 2 & 29 & 14 & 4 \\
\hline $\begin{array}{l}\text { Medvedev, } \\
2009 \text { (9826) }\end{array}$ & 8 & 1 & 4 & 10 & - & 10 \\
\hline
\end{tabular}


We set ourselves the objective of building an effectively functioning executive vertical power structure, ensuring legal discipline and creating an effectively functioning judicial system. $<\ldots>$

All of this took place as the economic situation remained favourable. The Russian economy experienced growth rates unseen in almost 30 years in 2000. Growth continues in some industrial sectors today. Investment activity is on the rise, more taxes are being collected and people are finally being paid their wages and pensions on time for the first time in years. (Putin, 2001)

Nevertheless, in 2005 Putin shows his adherence to the democratic ideology and resorts to such words as democratic/democracy and free/freedom. The following years $(2006,2007)$ reflect the recurrent tendency of the rollback of democratic principles, repeating the situation of 2000-2004:

I consider the development of Russia as a free and democratic state to be our main political and ideological goal. We use these words fairly frequently, but rarely care to reveal how the deeper meaning of such values as freedom and democracy, justice and legality is translated into life. $\langle\ldots>$

We proceed from the idea that it is both essential and economically advantageous to have developed democratic procedures in the country; that it is politically prudent to maintain a responsible dialogue with society. Therefore, a modern Russian official must learn to speak with the public using the modern language of cooperation, the language of common public interest, dialogue and real democracy, rather than the jargon of military orders. (Putin, 2005)

D. Medvedev revives the importance of democratic values paying special attention to the use of words democratic/democracy, free/freedom, responsible/responsibility in his Address of 2008:

Our values form our vision of the future. We aspire to a fair society of free people. We know that Russia will be a prosperous and democratic country. It will be a strong country that offers its people a comfortable life. It will be the best country in the world for the most talented, demanding, independent and critically-inclined citizens. $\langle\ldots\rangle$

Today, at a new stage in its development, Russian society affirms its commitment to the Constitution's democratic values. It has for the most part become familiar with the practice and procedures of democracy. $\langle\ldots\rangle$

Not so long ago, 15 years ago, people were still asking themselves whether or not democracy was the road forward for Russia. Today the answer is clear, democracy is the way forward, and no one disputes this now. The question today is how Russia's democracy should continue its development. $\langle\ldots\rangle$

We also need to entrust a growing number of social and political responsibilities directly to our citizens, their organisations and local self-government. Of course the state will retain the responsibilities that fall within its 
jurisdiction, and action must be pragmatic and accompanied by a sober assessment of the risks, but action is necessary. (Medvedev, 2008)

What we suggest here is that by propagating democratic principles the powerful try to create a shorter distance to the public. This relationship is explicitly indicated throughout the text. However, if we want to look at the situation "from below", as Hofstede recommends, some statistics may be of use for this purpose.

Table 2 presents the results of the survey on the following issue: "Some feel that we should rely on a democratic form of government to solve our country's problems. Others feel that we should rely on a leader with a strong hand to solve our county's problems. Which comes closer to your opinion?"

As we can see, according to the Pew Research Center in the immediate aftermath of the dissolution of the Soviet Union, $51 \%$ of Russians had faith in a democratic form of government to solve the country's problems, a larger number than had faith in a strong leader (39\%) to do the same. By 2002, the pattern had reversed to its current status with more Russians having faith in a strong leader than in a democratic government (http://pewresearch.org/pubs/749/ russia-public-opinion):

Table 2. Best Kind of Governance for Russia

\begin{tabular}{|l|c|c|c|}
\hline & $\begin{array}{c}\text { Democratic } \\
\text { Governance }\end{array}$ & $\begin{array}{c}\text { Strong } \\
\text { Leader }\end{array}$ & DK \\
\hline & $\mathbf{\%}$ & $\mathbf{\%}$ & $\mathbf{1 0}$ \\
\hline Spring, 2007 & 27 & 63 & 10 \\
\hline Spring, 2006 & 29 & 61 & 6 \\
\hline May, 2005 & 28 & 66 & 9 \\
\hline Summer, 2002 & 21 & 70 & 10 \\
\hline Fall, 1991 & 51 & 39 & $\mathbf{6}$ \\
\hline
\end{tabular}

Similarly, according to the data obtained from Russian Public Opinion Research Center (VCIOM), the majority of Russians believe that order is more important for Russia than democracy (http://wciom.com/news/press-releases/ press-release/single/13451.html). The results of the survey are presented in table 3 .

To get a more vivid picture of the situation let us turn to the analysis of the blog of the President of Russia D. Medvedev, which was created in 2009 and has become a resource frequently visited by Russian citizens. The main idea of the blog is to get feedback from the people of the country and start the 
exchange of opinions which will represent the reaction of the public to the issues covered by the President. Judging by this, we can say that the powerful try to create an image of transparent and democratic authorities ready for the dialogue with the members of the Russian society.

Table 3. The importance of order and democracy for Russia

\begin{tabular}{|l|c|c|c|c|}
\hline \multicolumn{6}{|c|}{ What is more important now for Russia? (close-ended question, one answer) } \\
\hline & $\mathbf{1 9 9 8}$ & $\mathbf{1 9 9 9}$ & $\mathbf{2 0 0 0}$ & $\mathbf{2 0 1 0}$ \\
\hline $\begin{array}{l}\text { Order even if for its achievement it } \\
\text { has to break some democratic prin- } \\
\text { ciples and limit personal freedoms }\end{array}$ & 69 & 74 & 75 & 72 \\
\hline $\begin{array}{l}\text { Democracy even if consecutive ob- } \\
\text { servance of democratic principles } \\
\text { gives some freedom to destructive } \\
\text { and criminal groups }\end{array}$ & 15 & 11 & 13 & 16 \\
\hline Hard to tell & 15 & 14 & 13 & 12 \\
\hline
\end{tabular}

The analysis of the messages shows that two polar points of view are represented in the blog - the belief in openness of the power and complete disbelief in it. There are supporters who believe in the created image of power and shorter distance established, and non-believers who deny it. Reactions of both groups can be found in the blog and both groups deserve consideration. For the present research the latter is more relevant, and we are going to focus on it.

Let us have a close look at the linguistic means used to render these ideas. The example represents the opinion of non-believers.

***I am grateful to you for the participation in open debates on the new political strategy**** (the commentary given by President D. Medvedev).

Thanks a lot. But how did we help if the Address does not differ from the article at all? As for me, I can't see any changes concerning exact proposals of people. But in fact, thanks a lot, once again.

Who is the President going to fulfill the set goals with? In fact, where is this country described, here? We hoped that Dmitrii Anatolyevich Medvedev would at least learn about the life of the country from blogs. None of his plans will come true if the President doesn't evaluate the situation objectively (http://blog.kremlin.ru/post/34).

Although in many messages we can observe the elements of the conversational style (the use of personal pronouns $\left[2^{\text {nd }}\right.$ person], rhetorical questions, question-and-answer sets, exclamatory sentences), the formal style is preserved, revealing the high distance between the powerful and the common people, i.e. 
the authors of the messages. While the powerful try to shorten the distance, the people insist on keeping it, which is rendered in the choice of formal words.

School reform. Can you explain how those who haven't received pedagogical education are allowed to teach at school? Can you imagine a teacher who is not familiarized with psychology and pedagogy? It will not work with our youth, who have absolutely different priorities in life, as compared with the earlier times. Is it possible to assess the results of the Unified State Exam? The old system of exams is much more efficient (in my opinion). And the majority of pupils will not be able to get a certificate after finishing school! (http:// blog.kremlin.ru/post/34).

The hierarchy in the interaction of the powerful and society is made manifest in the commentaries given by people, when the opposition of certain lexical units is presented, e.g. higher-ups and masses, officials and common people, bureaucracy and people:

It is given: higher-ups do only those things which are profitable for them personally, the destruction of the country does not concern them at all (officials starting with the head of the rural settlement), the masses (including us), not the worst people, fight for survival. (http://blog.kremlin.ru/post/34).

In sum, the results of the research prove that a certain (high or low) communicative distance can be observed in the interaction between the powerful and the public. Historically, a high power distance is typical of Russian interaction between the powerful and the public. Nowadays, despite the fact that Russian authorities try to establish a lower distance with the masses, the traditional high distance of power is preserved in Russian society. Political leaders endeavor to inculcate new ideologies promoting democratic principles, but the gap between political ideologies and cultural values still exists. The high distance is retained partly because the words of the powerful are not supported by practical deeds and positive results, and partly due to the fact that the high distance of power is rooted in the culture itself.

\section{INDIVIDUALISM VS COLLECTIVISM: \\ WHICH OF THE TWO IS TO WIN IN RUSSLA?}

The next dimension we are going to address in the article is closely related to the Power Distance, and it is the dimension "Individualism versus Collectivism". Hofstede defines it as follows:

Individualism on the one side versus its opposite, collectivism, is the degree to which individuals are integrated into groups. On the individualist side we find societies in which the ties between individuals are loose: everyone is expected to look after her/himself and her/his immediate family. On the collectivist 
side, we find societies in which people from birth onwards are intergrated into strong, cohesive in-groups, often extended families (with uncles, aunts and grandparents) which continue protecting them in exchange for unquestioning loyalty (www.geerthofstede.nl).

The scholar claims that in his understanding the word 'collectivism' has no political meaning. However, individualism or collectivism as cultural values can be transformed into political ideologies, in which cases they become legitimised by means of laws and official approval. At a certain point it becomes difficult to say whether individualism or collectivism in a society is inherent in national mentality or presents a social effect of consistent ideological work performed by the powerful.

Discussing the problem of individualism and collectivism in western and eastern cultures, Scollon \& Scollon report that individualism "has its roots in the western tradition going back to Socrates or to Jesus", and "there is a long tradition of emphasizing the separation of the individual from any other social commitments, especially in the pursuit of social or political goals" (Scollon, Scollon 2005: 144). The view of the self in eastern cultures is quite different. The Chinese scholar Hsu argues that culture and society are primary realities in themselves, and human relationships are the fundamental units of analysis, not secondary, constructed categories (Hsu 1985). According to Hsu, the Chinese concept of person includes relationships with other people, society and culture. Making an attempt at finding the golden mean between the two opposite concepts of an individual, the Scollons state: "We believe that in any society human individuals must have close relationships with other humans as well as the freedom to operate independently" (Scollon, Scollon 2005: 146).

Even more significant is the conclusion drawn by the scholars:

What is important in studying cultural differences is not whether a society is individualistic or collectivistic in itself, but what that society upholds as its ideal, even when we all recognize that we must all have some independence as well as some place in society (Scollon, Scollon 2005: 146).

What ideal is upheld in Russia? Does Russian culture tend to be more individualist or collectivist? What about ideologies imposed from above? What ideals do they inculcate? Most scholars of Russian culture and history emphasise the collectivist character that has always been typical of Russian society. Kasyanova, a scholar in Russian cultural studies, mentions the factors usually blamed aimed at the Russians for extreme collectivism (Касьянова 1994: 130). Wierzbicka notes that in Russian culture an individual is not expressed sufficiently, he does not act as an autonomous agent who is striving to achieve his purposes and control events (Вежбицкая 1997: 33). As if responding to Wierzbicka's remarks on the lack of agency of Russian individuals, Gachev observes that in 
Russia it is the State that has always been the agent of constructing activity, not an individual. The State as the Whole is primary, while individuals are its functions (Гачев 1998: 223). This statement highlights a principal point: the connection is established between individualism, or rather a lack of it, and the state power. The stronger the state is and the more important its role is in the life of the country, the less perceptible an individual is, with his own needs and rights.

At the same time, even without being practised as an ideology, collectivism will remain inherent in Russian mentality and be made manifest in different ways in everyday life. As Richmond correctly notes, "Russian communalism is not an invention of Communists, although its traditions were exploited under the Soviets" (Richmond 1992: 14). It may be inferred from what has been written above that cultural values and ideologies are interconnected, and the former may be used, or even abused, by the latter.

The term 'communalism' in Richmond's comment deserves consideration, because it is not just a question of wording. The scholar uses it as a synonym of the Russian word 'sobornost' and states: "Sobornost (communal spirit, togetherness) distinguishes Russians from Westerners for whom individualism and competitiveness are more common characteristics" (Richmond 1992: 14). The term 'sobornost' is used instead of 'collectivism' in many other studies (Мединский 2009; Уфимцева 2000; Мяло 1996). The point is that sobornost is not viewed as equal to collectivism, and Myalo explains the difference between the two. Sobornost does not presuppose absolute dissolution of an individual in a crowd. It is not a mechanical union of 'social atoms', like in collectivism. Sobornost presupposes spirituality of individuals and their own freedom in joining a group (Мяло 1996: 84). Thus, sobornost preserves individuals as free members of a group who are able to help and support each other.

In our view, Hofstede's scale "individualism versus collectivism" is not designed to accommodate Russian sobornost which is a concept in some way different from collectivism proper. The scale has a quantitative character, while the difference between collectivism and sobornost is not a matter of degree only; it is qualitative.

Scollon \& Scollon express a similar view assuming there are various forms of individualism. Developing individualism in Asia does not have much in common with American individualism, i.e. the difference is qualitative (Scollon, Scollon 2005: 238).

The evidence about possible qualitative variation of individualism and collectivism leads us to the conclusion that the dimension "individualism versus collectivism" is not actually a linear construct, and to get a complete picture of this dimension quantitative analysis will not suffice.

In the following part of the article with linguistic analysis we pose the following questions. What is the present ideal of Russian society in terms of "individualism - collectivism" as this ideal is presented in presidential discourse? 
Which of the values do the modern leaders preach: western individualism, Russian sobornost where every individual is a valuable part of a community, or collectivism with a group as a primary entity? To what extent, if any, are cultural values as unconscious entities transformed into ideologies as conscious directives?

To answer these questions, we shall 'filter' out linguistic expressions that set up the recurring discourse referents.

Our assumption is that in the individualistic culture discourse is penetrated by the ' $I$-line' as the pronoun $I$ is a means of structuring personal identity: 1 pers. sg. pronoun is used to express one's point of view, to describe personal experience and attitude towards different issues. The collectivist culture presupposes minimal use of personal identity markers and focuses on larger entities, such as society, people, nation, etc. Let us proceed on this hypothetical assumption. In table 4 we present the results of quantitative analysis of various lexical nominations used to refer to different members and groups of the society.

As we can see in table 4, Russian leaders often resort to using the pronoun $I$, but the pronoun we predominates in the analysed discourse. The text works by steadily repeating the pronouns we/our. Both Putin and Medvedev refer mainly to the country, state, people, citizens, whereas definite groups (students, young people, servicemen, teachers, etc.) are represented by isolated instances.

What is noteworthy about Medvedev's texts is not only recurrence of references to different agents, but also the extent to which these agents are overtly specified. There is a considerable increase in the use of the pronoun $I$ and references to an individual, which can be evidence for a shift towards a more individualized approach in addressing the public and to pursuing a more liberal policy:

The cult of the state and the illusory wisdom of the administrative apparatus have prevailed in Russia over many centuries. Individuals with their rights and freedoms, personal interests and problems have been seen as at best a means and at worst an obstacle for strengthening the state's might. This view endured throughout many centuries. $\langle\ldots\rangle$

This is why the adoption in 1993 of a Constitution proclaiming the individual, their life, rights and property as the highest value was an unprecedented event in Russia's history, and we should thank all those who took part in drafting and adopting this document. (Medvedev, 2008);

Through our joint efforts, not only will our living standards show real improvement but we ourselves will change too. We need to overcome the widespread view that responsibility for sorting out all problems lies with the state or with whoever else, but not with each of us personally. Personal success, encouragement of initiative, a better quality of public discussion, and zero tolerance of corruption should become part of our national culture, an intrinsic part of who we are. (Medvedev, 2009). 
Table 4. Linguistic means of addressing to different members of society

\begin{tabular}{|c|c|c|c|c|c|}
\hline & 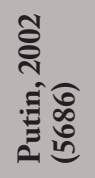 & 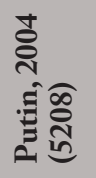 & 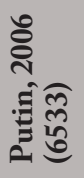 & 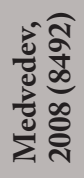 & 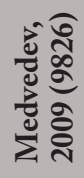 \\
\hline $\mathrm{I} / \mathrm{my}$ & 12 & 5 & 11 & 30 & 54 \\
\hline We/our & 104 & 98 & 142 & 159 & 219 \\
\hline You/your & 9 & 1 & 19 & 9 & 4 \\
\hline $\begin{array}{l}\text { Country } \\
\text { State }\end{array}$ & $\begin{array}{c}16 \\
8\end{array}$ & $\begin{array}{l}26 \\
16\end{array}$ & $\begin{array}{l}28 \\
15\end{array}$ & $\begin{array}{l}25 \\
24\end{array}$ & $\begin{array}{l}42 \\
18\end{array}$ \\
\hline Russia & 24 & 32 & 33 & 12 & 40 \\
\hline $\begin{array}{l}\text { People } \\
\text { Popu- } \\
\text { lation } \\
\text { Nation } \\
\text { Citizens }\end{array}$ & $\begin{array}{c}13 \\
10 \\
- \\
24\end{array}$ & $\begin{array}{c}32 \\
6 \\
1 \\
23\end{array}$ & $\begin{array}{l}13 \\
1 \\
- \\
9\end{array}$ & $\begin{array}{c}36 \\
3 \\
6 \\
30\end{array}$ & $\begin{array}{c}37 \\
8 \\
2 \\
17\end{array}$ \\
\hline Society & 3 & 11 & 6 & 23 & 17 \\
\hline Family & 1 & 6 & 16 & 3 & 5 \\
\hline $\begin{array}{l}\text { Youth/ } \\
\text { young }\end{array}$ & - & 4 & 10 & 2 & 10 \\
\hline Children & 2 & 2 & 8 & 3 & 10 \\
\hline Students & 2 & 1 & - & - & - \\
\hline $\begin{array}{l}\text { Everyone/ } \\
\text { every } \\
\text { person }\end{array}$ & $\begin{array}{l}1 \\
-\end{array}$ & $\begin{array}{l}4 \\
7\end{array}$ & - & $\begin{array}{l}10 \\
15\end{array}$ & $\begin{array}{l}6 \\
5\end{array}$ \\
\hline
\end{tabular}

The example given above provides a direct answer to the question on what Russia is seeking for - it is sobornost, where every person is an inseparable and meaningful part of a community.

Nevertheless, the country's interests are of utmost importance, which also constitutes a typical characteristic of the genre of Presidential Address:

Second, we need to work hard to protect the uniqueness of our country's culture in all its diversity, to help preserve the rich ethnic traditions of Russia's peoples, and at the same time develop and improve Russian language 
programmes, which serve as the basis for communication and unity in our country (Medvedev, 2009).

Given this evidence, it can be seen that modern presidential discourse relies on traditional Russian values: appeals to communal spirit help the powerful to emphasize the importance of the country's interest. However, along with propagating collective purposes, the value of an individual is being stressed, which can be interpreted as an attempt to inculcate new ideologies in the society after a long period of Soviet collectivism.

\section{CONCLUSION}

The analysis of political discourse carried out in the present paper has supported our assumption that political ideologies can be based upon traditional cultural values, and together with language these entities form a tripartite unity.

Hofstede's theory of cultural dimensions appears to be an efficient framework for characterizing cultural and ideological space of the modern Russia. Focusing attention on two principal dimensions that are essential for understanding power relations (Power Distance, Individualism vs. Collectivism), we have singled out a number of principal ideologically meaningful concepts in speeches of Russian presidents, which embody a new polity and values introduced in the society. The evidence seems to be strong that there is a gap between newly inculcated democratic principles and traditionally high power distance.

In our opinion, Hofstede's linear scale "Individualism vs. Collectivism" has certain limitations and cannot accommodate the Russian traditional concept of 'sobornost' which unites propagating communal interests and, simultaneously, the value of an individual. Both elements of sobornost can be discovered in Russian presidential discourse, which proves once again that the powerful resort to traditional cultural values when attempting at introducing certain ideologies.

\section{REFERENCES}

Ardichvili, A., Kuchinke, K.P. (2002). "Leadership styles and cultural values among managers and subordinates: a comparative study of four countries of the former Soviet Union, Germany, and the US". HRDI 5: 1, 99-117.

Blommaert, J. (2005). Discourse: A Critical Introduction (Key Topics in Sociolinguistics). Cambridge University Press.

-, (2006). Language ideology. Encyclopedia of Language and Linguistics. Elsevier. 510-522.

Dye, T.R., Zeigler, H. (2008). The Irony of Democracy: An Uncommon Introduction to American Politics. Wadsworth Publishing.

Fairclough, N. (2004). Analysing Discourse: Textual Analysis for Social Research. London, New York: Routledge. 
GeE, J.P. (1999). An Introduction to Discourse Analysis: Theory and Method. London: Routledge.

Hofstede, G. Dimensions of national cultures. www.geerthofstede.nl/culture/dimensions-of-national-cultures.aspx

-, (2001). Culture's Consequences: comparing values, behaviors, institutions, and organizations across nations (2nd ed.). Thousand Oaks, CA: SAGE Publications.

Hsu, F.L.K. (1985). The self in cross-cultural perspective. In Anthony J. Marsella, George DeVos, and Francis L.K. Hsu (eds), Culture and Self: Asian and western perspectives, New York: Tavistock Publications.

Kitaigorods kaya, M.V., Rozanova, N.N. (1998). Contemporary Political Communication: Trends of Development. Dialoganalyse VI. Referate der 6. Arbeitstagung Prag 1996. Tuebingen, Max Niemeyer Verlag. 245-251.

The Merriam-Webster Dictionary (1995). Merriam-Webster.

Richmond, Y. (1992). From Nyet to Da. Understanding the Russians. Intercultural Press.

Scollon, R., Scollon, S.W. (2005). Intercultural Communication: A Discourse Approach. Oxford: Blackwell.

ВЕЖБИЦКАЯ А. (1997). Язык. Культура. Познание. М.: Русские словари.

ВОЛОШИН М. (1990). Россия распятая. Юность 10, $24-31$.

ГАЧЕВ Г.Д. (1998). Национальные образы мира. М.: Издательский центр «Академия».

КАСЬЯНОВА К. (1994). О русском национальном характере. М.

МЕДИНСКИЙ В.Р. (2009). О русском воровстве, особом пути и долготерпении. М.: ОЛМА Медиа Групп.

МЯДО К.Г. (1996). О русском идеале. Евразия 1(4), 77-85.

СИКЕВИЧ З.В. (1996). Национальное самосознание русских. (Социологический очерк). М.: Механик.

Словарь русского языка (1999): В 4-х т. / РАН, Ин-т дингвистич. исследований. - 4-е изд., стер. М.: Рус. яз.; Полиграфресурсы.

\section{DATA}

Presidential Address to the Federal Assembly of the Russian Federation (1994). http:// www.intelros.ru/2007/02/04/poslanija_prezidenta_rossii_borisa_elcina_federalnomu_sobraniju_rf_1994_god.html

Presidential Address to the Federal Assembly of the Russian Federation (1995). http:// www.intelros.ru/2007/02/05/poslanie_prezidenta_rosii_borisa_elcina_federalnomu_sobraniju_rf_o_dejjstvennosti_gosudarstvennojj_vlasti_v_rossii_1995_god. html

Presidential Address to the Federal Assembly of the Russian Federation (1996).

http://www.intelros.ru/2007/02/05/poslanie_prezidenta_rosii_borisa_elcina_federalnomu_sobraniju_rf_rossija_za_kotoruju_my_v_otvete_1996_god.html

Presidential Address to the Federal Assembly of the Russian Federation (1997). 
http://www.intelros.ru/2007/02/05/poslanie_prezidenta_rosii_borisa_elcina_federalnomu_sobraniju_rf_porjadok_vo_vlasti__porjadok_v_strane_1997_god.html

Presidential Address to the Federal Assembly of the Russian Federation (1998).

http://www.intelros.ru/2007/02/05/poslanie_prezidenta_rosii_borisa_elcina_federalnomu_sobraniju_rf_obshhimi_silami_k_podemu_rossii_1998_god.html

Presidential Address to the Federal Assembly of the Russian Federation (1999).

http://www.intelros.ru/2007/02/05/poslanie_prezidenta_rosii_borisa_elcina_federalnomu_sobraniju_rf_rossija_na_rubezhe_jepokh_1999_god.html

Presidential Address to the Federal Assembly of the Russian Federation (2000).

http://www.intelros.ru/2007/01/17/poslanie_prezidenta_rossii_vladimira_putina_federalnomu_sobraniju_rf_2000_god.html

Presidential Address to the Federal Assembly of the Russian Federation (2001).

http://www.intelros.ru/2007/01/17/poslanie_prezidenta_rossii_vladimira_putina_federalnomu_sobraniju_rf_2001_god.html

Presidential Address to the Federal Assembly of the Russian Federation (2002).

http://www.intelros.ru/2007/02/05/poslanie_prezidenta_rossii_vladimira_putina_federalnomu_sobraniju_rf_2002_god.html

Presidential Address to the Federal Assembly of the Russian Federation (2003).

http://www.intelros.ru/2007/02/05/poslanie_prezidenta_rossii_vladimira_putina_federalnomu_sobraniju_rf_2003_god.html

Presidential Address to the Federal Assembly of the Russian Federation (2004).

http://www.intelros.ru/2007/02/05/poslanie_prezidenta_rossii_vladimira_putina_federalnomu_sobraniju_rf_2004_god.html

Presidential Address to the Federal Assembly of the Russian Federation (2005).

http://www.intelros.ru/2007/02/05/poslanie_prezidenta_rossii_vladimira_putina_federalnomu_sobraniju_rf_2005_god.html

Presidential Address to the Federal Assembly of the Russian Federation (2006).

http://www.intelros.ru/2007/02/05/poslanie_prezidenta_rossii_vladimira_putina_federalnomu_sobraniju_rf_2006_god.html

Presidential Address to the Federal Assembly of the Russian Federation (2007).

http://www.intelros.ru/2007/02/05/poslanie_prezidenta_rossii_vladimira_putina_federalnomu_sobraniju_rf_2007_god.html

Presidential Address to the Federal Assembly of the Russian Federation (2008). http://www.kremlin.ru/transcripts/1968

Presidential Address to the Federal Assembly of the Russian Federation (2009). http://www.kremlin.ru/transcripts/5979

Videoblog of President of Russia D. Medvedev (2009). http://blog.kremlin.ru/

\section{ACKNOWLEDGEMENTS}

We are indebted to Dr. Isabel Iñigo-Mora who invited us to participate in the volume and provided necessary support during the process of preparing the paper. 
Many thanks also go to Prof.Jim Butterfield who took the trouble to become our volunteering editor and whose comments on the contents and help as to the English language use are most appreciated. We are, of course, responsible for any surviving drawbacks. 
